\title{
Al-chizan
}

ISSN 1907-0985, E ISSN 2442-8256

Vol. 16, No. 1, 2020, h. 27-50

DOI: https://doi.org/10.30603/am.v16i1.1397

\section{Hukum Islam dan Penggunaan Teknologi Informasi di Indonesia}

\author{
Muhammad Gazali Rahman, Limyah Alamri, Ardin Bataweya \\ IAIN Sultan Amai Gorontalo \\ Email: gazali.iain@gmail.com; limyahalamri901@gmail.com; \\ bataweyaardin@gmail.com
}

\begin{abstract}
This paper discusses the relationship between Islamic law and the use of information technology, especially in Indonesia. This research is a library research with the data source in the form of documentation. The results showed that information disclosure in society was due to the development of sophistication in information technology. Everything that happens in other parts of the world in seconds can be known by humans in other parts of the world. Technology was created to serve and facilitate humans in carrying out their life activities. The use of the right information technology can have a positive impact, but the use of inappropriate information technology can have a negative impact. Historical facts in the Islamic world are known to the openness of Muslims to all information in developing Islamic intellectual treasures. In the teachings of Islam, it is found that Allah's affirmation through QS alHujurāt/49 verse 12 against facing advances in information technology. Information technology cannot be separated in the development of Islamic law because it can be a tool or media in researching and analyzing a law and developing legal information for the wider community.
\end{abstract}

Keywords: Islamic Law, Information Technology, Indonesia

\section{Islamic Law and Use of Information Technology in Indonesia}

Abstrak: Tulisan ini mendiskusikan tentang hubungan hukum Islam dengan penggunaan teknologi informasi, khususnya di Indonesia. Penelitian ini adalah penelitian kepustakaan dengan sumber data berupa dokumentasi. Hasil penelitian menunjukkan keterbukaan informasi pada masyarakat dikarenakan semakin berkembangnya kecanggihan dalam teknologi informasi. Segala sesuatu yang terjadi di belahan dunia dalam hitungan detik dapat diketahui oleh manusia di belahan dunia lainnya. Teknologi diciptakan untuk melayani dan memudahkan manusia dalam menjalankan aktifitas kehidupannya. Penggunaan teknologi informasi yang tepat dapat memberikan dampak yang positif, namun penggunaan teknologi informasi yang tidak tepat dapat memberikan dampak yang negatif. Fakta sejarah dalam dunia Islam diketahui keterbukaan umat Islam terhadap segala informasi dalam mengembangkan khazanah intelektual Islam. Dalam ajaran Islam pun ditemukan penegasan Allah melalui QS al-Hujurāt/49 ayat 12 terhadap menghadapi kemajuan teknologi informasi. Teknologi informasi tidak dapat dipisahkan dalam perkembangan hukum Islam dikarena dapat menjadi alat atau media dalam meneliti dan menganalisis sebuah hukum serta mengembangkan informasi hukum pada masyarakat luas.

Kata Kunci: Hukum Islam, Teknologi Informasi, Indonesia 


\section{A. Pendahuluan}

Memasuki abad ke 21, dunia berada pada era yang dikenal dengan era modern, kegiatan industri atau pemanfaatan teknologi hampir semua segi kehidupan lebih mengemuka. Penyebutan zaman modern dan era modernisasi saat ini, jika dilihat dari hakikat substansinya akan lebih tepat disebut era teknik, karena ditandai dengan peran sentral teknologi informasi dalam seluruh segi kehidupan manusia.

Istilah teknologi informasi mulai populer di akhir tahun 70-an. Pada masa sebelumnya istilah teknologi informasi biasa disebut teknologi komputer atau pengolahan data elektronis (electronic data processing). Teknologi informasi didefinisikan sebagai teknologi pengolahan dan penyebaran data menggunakan perangkat keras (hardware) dan perangkat lunak (software), komputer, komunikasi, dan elektronik digital. ${ }^{1}$

Teknologi dalam berbagai bentuk dan fungsinya merupakan produk ilmu pengetahuan. Dalam sudut pandang budaya, teknologi merupakan hasil penerapan praktis dari ilmu pengetahuan meskipun pada dasarnya teknologi juga memiliki karakteristik, obyektif, dan netral. Dalam situasi tertentu teknologi tidak netral lagi karena memiliki potensi untuk merusak dan potensi kekuasaan, di sinilah letak perbedaan ilmu pengetahuan dengan teknologi.

Teknologi dapat membawa dampak positif berupa kemajuan dan kesejahteraan bagi manusia juga sebaliknya dapat membawa dampak negatif berupa ketimpanganketimpangan dalam kehidupan manusia dan lingkungannya yang berakibat kehancuran manusia itu sendiri. Kemajuan ilmu pengetahuan dan teknologi telah membawa perubahan bagi masyarakat, baik di dalam cara berpikir, sikap maupun tingkah laku. Dari satu sisi kemajuan ilmu pengetahuan dan teknologi telah membuat manusia lebih sempurna dalam menguasai, mengolah dan melestarikan alam untuk kepentingan dan kesejahteraan hidup manusia. Namun dari sisi lain kemajuan ilmu pengetahuan dan teknologi telah merusak dan meracuni sisi mental dan moral generasi muda yang begitu mudah mangakses film-film porno dan porno aksi.

\footnotetext{
${ }^{1}$ Oemar Hamalik, Kurikulum dan Pembelajaran (Cet. III; Jakarta: Bumi Aksara, 2001), 16.
} 
Teknologi informasi telah menjadi kebutuhan primer setiap orang. Sayangnya, teknologi informasi tidak sepenuhnya mampu menjadi media informasi, pendidikan, hiburan yang sehat, kontrol sosial, dan perekat sosial yang diharapkan. Televisi misalnya, fungsi media informasinya hanya sekitar 30 persen saja. Selama 24 jam, televisi hanya menayangkan 2-3 jam berita yang penuh informasi dan objektif. Sisanya, masyarakat penggemar televisi disuguhi acara tidak bermanfaat. Generasi bangsa dididik menjadi kaum cinta dunia dimana kebahagiaan dinilai dengan materi. Adalah sebuah prestasi membanggakan bagi sebagian orang tua ketika anaknya menjadi selebritis yang mencontohkan gaya hidup hedonis dibandingkan ketika anaknya menjadi seorang guru pencetak kader bangsa berkualitas.

Pada sisi lain, perkembangan ilmu pengetahuan dalam era globalisasi merupakan salah satu ciri utama dari masyarakat masa depan. Perkembangan ilmu pengetahuan dan teknologi pada akhir abad ke 20 ini sangat mengesankan, utamanya dalam bidang-bidang transportasi, telekomunikasi informatika dan sebagainya. Perkembangan tersebut lebih cepat dari yang diprediksikan. Demikian pula dampaknya bersifat global. Perkembangan ilmu pengetahuan dan teknologi tersebut berpengaruh terhadap perkembangan masyarakat baik positif ataupun negatif, terletak pada kesiapan masyarakat dan kondisi sosial budayanya untuk menerima limpahan informasi teknologi. Segi posistifnya, memudahkan bagi masyarakat untuk mengakses informasi dan memanfaatkannya sebagai media komunikasi dan dakwah dalam menyadarkan masyarakat untuk menerapkan nilai-nilai agama dalam kehidupannya. Sedangkan segi negatifnya akan menimbulkan penyakit sosial illnes epedemi, yakni kondisi sosial budaya masyarakat belum siap menerima sebuah perkembangan yang sangat cepat.

\section{B. Realitas Perkembangan Teknologi Informasi}

Teknologi berasal dari kata latin tekne dan dalam bahasa Inggris disebut art yang berarti seni dan $\log o s$ dalam bahasa Indonesia yakni ilmu. ${ }^{2}$ Teknologi adalah aplikasi kreatif daripada ilmu pengetahuan untuk maksud-maksud industri atau sesuatu yang

\footnotetext{
${ }^{2}$ Jhon M. Echols dan Hassan Shadily, Kamus Inggris Indonesia (Cet. XXI; Jakarta: Gramedia,
} 1995), 39. 
praktis. ${ }^{3}$ Menurut Webster, art adalah keterampilan (skill) yang diperoleh melalui pengalaman, studi, dan observasi. ${ }^{4}$ Oemar Hamalik memberikan batasan teknologi sebagai aplikasi kreatif daripada ilmu pengetahuan (science) untuk maksud-maksud industri atau sesuatu yang praktis. ${ }^{5}$ Mengutip pendapat Webster, Azhar Arsyad menyatakan bahwa teknologi adalah suatu ilmu yang membahas tentang keterampilan yang diperoleh melalui pengalaman, studi, dan observasi. ${ }^{6}$

Teknologi berarti penerapan ilmu atau suatu kumpulan ilmu pengetahuan yang praktis dan erat hubungannya dengan enjinering atau rekayasa, perindustrian dan sebagainya. ${ }^{7}$ Menurut Leksikon sebagaimana dikutip Udin Saefudin Sa'ud, technology adalah scientific study, yang memiliki pengertian: 1) kajian, telaah, penelitian yang sistematis, dan ilmiah. Dengan kata lain, teknologi adalah "ilmu" dalam pengertiannya yang luas; 2) teknologi adalah mechanical arts, yakni alat-alat mekanis (mesin); 3) teknologi berarti applied science, yaitu ilmu-ilmu terapan atau ilmu-ilmu praktis; 4) teknologi berarti application of this to practical task (aplikasi dari ilmu dan alat-alat untuk kepentingan atau pekerjaan harian). ${ }^{8}$

Amin Haedari mengartikan teknologi sebagai semua perwujudan alam yang direkayasa oleh manusia, sehingga tidak lagi "alami" seperti yang telah disajikan kepada manusia oleh sang pencipta. Perwujudan ini bisa terkait dengan bidang transportasi seperti kendaraan bermotor atau mobil, bidang pertanian seperti bibit tanaman unggul, bidang kesehatan seperti obat antibiotika, atau di bidang lainnya, termasuk teknologi di bidang komunikasi dan informasi seperti telepon seluler, kamera digital, komputer, jaringan internet, dan sebagainya. ${ }^{9}$

Definisi tersebut mengisyaratkan beberapa hal penting, yaitu: pertama, teknologi adalah ilmu tentang cara menerapkan sains; kedua, teknologi bersumber atau

\footnotetext{
${ }^{3}$ Kementerian Pendidikan Nasional, Kamus Besar Bahasa Indonesia (Cet. IX; Jakarta: Balai Pustaka, 2012), 1110.

${ }^{4}$ Azhar Arsyad, Media Pembelajaran (Cet. III; Jakarta: RajaGrafindo Persada, 2002), 5.

${ }^{5}$ Hamalik, Kurikulum dan Pembelajaran, 56.

${ }^{6}$ Arsyad, Media Pembelajaran, 5.

${ }^{7}$ Tim Prima Pena, Kamus Ilmiah Populer: Referensi Ilmiah Ideologi, Politik, Hukum, Ekonomi, Sosial, Budaya dan Sains (Surabaya: Gita Media Press, 2006), 459-460.

${ }^{8}$ Udin Saefudin Sa'ud, Inovasi Pendidikan (Cet. I; Bandung: AlfaBeta, 2008), 183.

${ }^{9}$ HM. Amin Haedari, et.al, Masa Depan Pesantren, dalam Tantangan Modernitas dan Tantangan Kompleksitas (Jakarta: IRD Press, 2004), 194-195.
} 
berkaitan erat dengan alam semesta; ketiga, tujuan penciptaan dan penerapan teknologi adalah untuk kenyamanan manusia. ${ }^{10}$ Dengan demikian, secara prinsip, teknologi tidak dapat dipisahkan dari alam dan manusia. Karena pada dasarnya, teknologi diciptakan untuk melayani dan memudahkan kehidupan manusia.

Pengertian informasi menurut Oxfoord English Dictionary adalah "that of which one is apprised or told; intelligence, news". ${ }^{11}$ Kamus lain menyatakan bahwa, informasi adalah sesuatu yang dapat diketahui. Namun, ada pula yang menekankan informasi sebagai transfer pengetahuan. Adanya perbedaan definisi informasi dikarenakan, pada hakikatnya, informasi tidak dapat diuraikan (intangible), sedangkan informasi itu dijumpai dalam kegiatan sehari-hari, yang diperoleh dari data dan dari observasi terhadap dunia sekitar kita serta diteruskan melalui komunikasi.

Teknologi informasi menurut Hamzah B. Uno dan Nina Lamatenggo adalah suatu teknologi yang digunakan untuk mengolah data yang dimana pengolahan itu termasuk memproses, mendapatkan, menyusun, menyimpan, memanipulasi data dalam berbagai cara untuk menghasilkan informasi yang berkualitas, yaitu informasi yang relevan, akurat dan tepat waktu. ${ }^{12}$ Secara sederhana, definisi teknologi informasi dapat diartikan sebagai teknologi yang digunakan untuk menyimpan, menghasilkan, mengolah, serta menyebarkan informasi. Definisi tersebut menganggap bahwa teknologi informasi tergantung pada kombinasi komputasi dan teknologi telekomunikasi berbasis mikroelektronik. ${ }^{13}$

Peranan media elektronika pada masyarakat informasi sangat memegang peranan penting dan bahkan menentukan corak kehidupan. Penggunaan teknologi elektronika seperti televisi (antena digital), komputer, faksimile, internet, dan lain-lain, telah mengubah lingkungan informasi dari lingkungan yang bercorak lokal dan nasional, kepada lingkungan yang bersifat internasional, mendunia, dan global. Pada era informasi, lewat komunikasi satelit dan komputer, orang memasuki lingkungan informasi dunia. Komputer bukan saja sanggup menyimpan informasi dari seluruh

\footnotetext{
${ }^{10}$ Sa’ud, Inovasi Pendidikan, 349.

${ }^{11}$ Joyce M. Hawkins, Oxford Universal Dictionary (Oxford: Oxford University Press, 1995), 492.

${ }^{12}$ Hamzah B. Uno dan Nina Lamatenggo, Teknologi Komunikasi dan Informasi Pembelajaran (Cet. II; Jakarta: Bumi Aksara, 2011), 57.

${ }^{13}$ Akmal Hawi, Kapita Selekta Pendidikan Islam (Palembang: IAIN Raden Fatah, 2005), 147.
} 
dunia, melainkan juga sanggup mengolahnya dan menghasilkannya secara lisan, tulisan, bahkan visual. ${ }^{14}$ Singkatnya, sarana teknologi informasi yang berkembang pesat sampai saat ini, memiliki sistem kerja dengan ciri kecanggihannya.

Namun perlu untuk diperhatikan, peran media elektronik yang demikian besar telah menggeser agen-agen sosialisasi yang berlangsung secara tradisional, seperti yang dilakukan oleh orang tua, guru, pemerintah, dan sebagainya. Komputer telah menjadi teman bermain, orang tua yang akrab, guru yang memberikan pesan, juga sewaktuwaktu dapat memberikan jawaban segera terhadap pertanyaan-pertanyaan eksitensial dan mendasar. Kemajuan dalam bidang teknologi komunikasi-informasi tersebut, pada akhirnya memberikan pengaruh pada kejiwaan dan kepribadian masyarakat. Menurut Abuddin Nata, pada era informasi yang sanggup bertahan hanyalah mereka yang berorientasi ke depan, yang mampu mengubah pengetahuan menjadi kebijakan, dan ciri-ciri lain sebagaimana dimiliki masyarakat modern. ${ }^{15}$

Semua masyarakat suatu bangsa dengan bangsa lain menjadi satu, baik dalam bidang sosial, budaya, ekonomi, dan sebagainya. Hal ini pada satu sisi ada baiknya dan banyak manfaatnya, yakni terjadinya pertukaran budaya, informasi, dan ilmu pengetahuan, sehingga dapat meningkatkan kualitas masing-masing. Namun di sisi lain, keterbukaan seperti ini juga memberikan dampak negatif yang tidak kecil, sehingga perlu kecermatan dalam menyeleksi informasi atau budaya.

Pesatnya perkembangan teknologi informasi saat ini dapat diartikan sebagai pisau bermata dua, karena selain memberikan kontribusi bagi peningkatan kesejahteraan, kemajuan, dan peradaban manusia, sekaligus dapat menjadi sarana efektif perbuatan melawan hukum bagi kalangan intelektualitas tertentu. Suatu hal yang tidak dapat dielakkan, bahwa pemanfaatan teknologi informasi, media, dan komunikasi telah mengubah baik prilaku masyarakat maupun peradaban secara global. $^{16}$

Pergeseran makna di dalam masyarakat terhadap perkembangan teknologi informasi dan komunikasi sangat signifikan dalam memaknainya sebagai alat dan

\footnotetext{
${ }^{14}$ Abuddin Nata, Paradigma Pendidikan Islam (Jakarta: Rajawali Press, 2009), 81-82.

${ }^{15}$ Ibid., 82.

${ }^{16}$ Republik Indonesia, Undang-Undang Republik Indonesia Nomor 11 Tahun 2008 tentang Informasi dan Transaksi Elektronik, Penjelasan Umum, alinea pertama.
} 
sarana informasi sekaligus komunikasi sebagai mobilitas bermasyarakat. Pentingnya menguasai teknologi hingga melahirkan jargon-jargon dalam kehidupan bermasyarakat seperti gapteg, tulalit, lola, dan sebagainya, bahkan jargon-jargon itu dilekatkan pada karakter pribadi seseorang, sehingga dalam pergaulan di masyarakat dapat diklasifikasikan sebagai kurang gaul. Hal ini menunjukkan bahwa teknologi saat ini merupakan budaya dalam masyarakat yang membawa peradaban baru yang tidak dapat dihindarkan. ${ }^{17}$

Tren pemberitaan media tentang kehidupan seseorang sebagai bagian dari era keterbukaan informasi dan pesatnya teknologi informasi semakin terasa saat ini. Apalagi, tentang mereka yang kebetulan berstatus penyanyi, bintang film, foto model, selebritis, dan mereka yang berkerja di dunia hiburan. Hampir tidak ada koran, majalah, televisi yang steril dari unsur pemberitaan. Jika ditarik dalam lingkup yang lebih luas, media informasi semakin dijejali berita dan gambar yang mengeksploitasi seks dan kekerasan.

Saat ini, sudah tidak asing lagi jika di media massa ditemukan berita tentang perselingkuhan, para remaja yang semakin vulgar bicara tentang seks, konsultasi seks, sampai tulisan tentang lika-liku kehidupan di atas ranjang. Foto-foto dan gambar seronok juga semakin sering menghiasi halaman-halaman internet, koran, dan tabloid. Berita perampokan dan pembunuhan sadis juga seringkali ditulis besar-besar di berbagai media yang menjadi bagian dari kemajuan teknologi informasi.

Ringkasnya negara-negara berkembang seperti Indonesia belum siap untuk menghadapi arus peradaban baru teknologi informatika tersebut, walaupun demikian tidak sedikit masyarakat Indonesia yang mempunyai kemampuan untuk menguasai peradaban baru tersebut terutama dari kalangan terpelajar yang berkiprah di bidang teknologi informatika. Sebagaimana dikatakan Syahdeini:

Dunia internet telah mempengaruhi pola hidup masyarakat Indonesia, ternyata ada masalah serius yang dihadapi oleh masyarakat Indonesia berkenaan dengan maraknya dunia internet. Masalah itu adalah masalah hukum, akan tetapi masalah hukum di dunia virtual tersebut belum banyak mendapat perhatian otoritas dan pengguna internet karena pemahaman yang masih dangkal mengenai aspek-aspek

${ }^{17}$ Niniek Suparni, Cyberspace Problematika dan Antisipasi Pengaturannya (Jakarta: Sinar Grafika, 2009), 1. 
hukum dari internet atau dari transaksi yang dilakukan dengan menggunakan sarana internet. ${ }^{18}$

Era informasi ini ditandai oleh semakin banyaknya tenaga kerja, kian terarahnya pikiran ke dalam kegiatan yang berhubungan dengan teknologi informasi. selain itu, era informasi juga ditandai dengan semakin berperannya teknologi informasi dalam kegitan ekonomi, politik, ideologi dan budaya. ${ }^{19}$

Arus budaya teknologi komputer, telekomunikasi, dan informatika di tengahtengah masyarakat begitu pesat bahkan sangat eksplosif, sehingga menimbulkan fenomena-fenomena baru di dalam sosial kemasyarakatan yang bisa berdampak negatif. Oleh karena itu, dengan hadirnya Undang-Undang Nomor 11 Tahun 2008 tentang Informasi dan Transaksi Elektronik dapat dikatagorikan sebagai pengaturan terhadap fenomena-fenomena baru yang tumbuh di tengah-tengah sosial kemasyarakatan Indonesia, agar dapat mencegah dampak yang negatif sebagai tindakan preventif sekaligus juga menaruh ekspektasi yang sangat besar untuk dapat mendorong dampak yang positif agar terjadi kondisi sosial yang harmonis di tengahtengah kehidupan bermasyarakat.

\section{Dampak Teknologi Informasi}

Saat ini manusia hidup di dalam abad informasi. Penemuan microchip dan perkembangan teknologi komputer mikro telah menimbulkan kekuatan yang memungkinkan diperolehnya informasi hanya dengan sentuhan sebuah tombol. Terdapat konsensus yang luas bahwa teknologi informasi yang secara tidak dapat dihindari akan memberi bentuk baru bagi masa depan umat manusia. ${ }^{20}$

Azizy mengemukakan teknologi informasi telah mendorong semakin lebih cepat proses pergeseran dari era machine age menuju system age yang ditandai dengan ciri-ciri berikut: 1) pergeseran dari pendekatan analisis menjadi pendekat an sintesis; 2)

${ }^{18}$ Sutan Remy Syahdeini, Kejahatan dan Tindak Pidana Komputer (Jakarta: Pustaka Utama Grafiti, 2009), 15.

${ }^{19}$ Marwah Daud Ibrahim, Teknologi Emansipasi dan Transendensi Wacana Peradaban dengan Visi Islami (Cet. II; Jakarta: Mizan, 1995), 186.

${ }^{20}$ Zainuddin Sardar, Information and the Muslim World; A Strategy for the Twenty-first Century, terj. Ilyas Hasan, Tantangan Dunia Islam Abad 21; Menjangkau Informasi (Bandung: Mizan, 1988), 13. 
pergeseran dari masyarakat mekanistik menjadi masyarakat organik; dan 3) pergeseran dari cara pandang reduksionis menjadi cara pandang holistik. ${ }^{21}$

Revolusi teknologi informasi kini sedang dijajakan sebagai suatu rahmat besar bagi manusia. Ditampilkan secara agresif di televisi, surat-surat kabar, dan majalahmajalah mewah dengan sangat menarik. Iklan-iklan berbagai produk, pemberitaan di berbagai belahan dunia, keterbukaan informasi publik, telah meniscayakan lahirnya demokrasi dan kemakmuran untuk semua lapisan masyarakat. Revolusi ini juga telah mengubah masyarakat secara radikal menjadi suatu masyarakat yang lebih manusia dan tercerahkan.. penyebaran besar-besaran teknologi informasi telah membawa manusia ke suatu peradaban elektronik, suatu lompatan panjang ke arah suatu peradaban yang lebih tinggi. ${ }^{22}$

Pada spektrum yang berbeda, abad informasi pada kenyataannya berdampak pada efek sebaliknya. Meningkatnya informasi tanpa filterisasi telah menghilangkan kemampuan individu dan lembaga negara dalam meningkatkan pengendalian atas keadaan masyarakat. Semakin banyak informasi yang telah menyebabkan semakin disadarinya bahwa segala sesuatu ternyatak tidak dapat dikendalikan. Informasi tentang perusakan lingkungan, kekacauan ekonomi, limbah beracun, akses keamanan nasional, keretakan rumah tangga, pencemaran nama baik, pembobolan rekening, hacking, manipulasi dan rekayasa data elektronik, transaksi seksual online, black market, semuanya mengarah kepada ketidakmampuan terhadap pengendalian sosial oleh negara. Bisa jadi, abad kemajuan teknologi informasi menjadi rahmat bagi sekelompok orang namun menjadi bencana bagi kelompok lainnya.

Perkembangan ilmu pengetahuan dan teknologi khususnya teknologi informasi saat ini telah mendominasi semua elemen kehidupan masyarakat, terutama pada generasi muda, tidak terkecuali pada masyarakat Islam. Akibat perkembangan teknologi ini cukup beragam, satu sisi kehidupan menjadi lebih dimudahkan, namun di sisi lain dirugikan. Ada banyak aspek yang harus diperhatikan akibat dampak dari penggunaan teknologi informasi ini terutama pada moralitas dan akhlak generasi muda Islam. Bahkan perkembangan teknologi tersebut tidak sedikit menghembuskan

\footnotetext{
${ }^{21}$ A. Qodri Azizy, Membangun Integritas Bangsa (Jakarta: Renaisan, 2004), 86-87.

${ }^{22}$ Ibid., 14.
} 
ideologi sekulerisme. Teknologi informasi yang notabenenya adalah produk budaya Barat, tentunya berbeda dengan budaya dan nilai-nilai ketimuran dan nilai Islam yang menjunjung tinggi kehormatan orang lain, keluhuran budi pekerti, etika, dan ketakwaan kepada Allah swt. ${ }^{23}$

Era globalisasi dunia telah berimplikasi kepada semakin banyaknya perubahan dalam menghayati arti kehidupan bagi manusia modern. Perubahan terhadap gaya hidup berorientasikan perkembangan teknologi informasi, juga mempengaruhi perkembangan budaya, pola pikir, dan gaya hidup yang bersendikan adat, etika, serta penghayatan terhadap norma agama dan nilai-nilai kemanusiaan.

Perubahan dunia saat ini sangat mungkin sebagai produk ledakan teknologi informasi. Hampir setiap hari muncul berbagai hasil ciptaan baru dari inovasi teknologi. Teknologi informasi telah berhasil menembus batas antar benua di seluruh dunia. Bahkan teknologi informasi telah berhasil mengubah pola pikir, ideologi, budaya dan berbagai elemen luar memasuki ruang negara lain tanpa batas dan pengawalan. Kasus di beberapa negara seperti gejolak politik di Mesir, membuktikan bahwa kekuatan jejaring sosial yang muncul karena pengaruh teknologi informasi, dapat melebihi kekuatan militer. Teknologi informasi sangat berharga dalam kehidupan manusia di era global, hingga turut menjadi penentu dan penggerak masa depan suatu bangsa.

Walaupun demikian,teknologi informasi menawarkan suatu solusi yang jauh lebih murah. Sebagian besar dunia Muslim dapat saling dihubungkan melalui telepon dalam waktu singkat melalui teknologi satelit. Di dalam aspek positif teknologi informasi pun terdapat banyak perangkap yang harus disadari. Aspek pertama di sini adalah pengendalian. Keuntungan-keuntungan teknologi informasi akan dipetik oleh mereka yang berhasil mengendalikan teknologi informasi. Dengan demikian, tidak banyak manfaatnya memiliki program-program canggih untuk membangun jaringanjaringan komunikasi untuk menghubungkan desa-desa terpencil, jika bergantung pada teknologi dari negara-negara industri. ${ }^{24}$

\footnotetext{
${ }^{23}$ Sardar, Information and the Muslim World, 17.

${ }^{24}$ Ibid., 76-77.
} 
Dengan ketergantungan seperti itu, kebijaksanaan yang baik sekalipun hanya akan mengarah kepada kebergantungan. Aspek yang kedua adalah ketidaklayakan. Teknologi informasi yang lahir di Barat cenderung mengarah kepada peningkatan elemen destruktif dan elemen pengendaliannya, atau secara spesifik sesuai untuk digunakan oleh konsumen-konsumen Barat. Inilah alasan penting menurut Sardar mengapa dunia Muslim harus mengembangkan kemampuan sendiri dalam bidang teknologi informasi. Gagal melakukan hal ini berarti memperkuat ketergantungan pada negara-negara industri, dan hal ini akan membuat negara-negara industri bukan hanya akan mempertahankan dominasi ekonomi dan politiknya, tetapi juga akan merongrong dan menaklukkan dunia Muslim. ${ }^{25}$

Potensi positif teknologi informasi dapat ditingkatkan hanya dengan mengevaluasi secara kritis teknologi tersebut dan memperikirakan manfaatnya bagi masyarakat dan kebudayaan Muslim melalui penilaian terhadap teknologi itu berdasarkan nilai-nilai konseptual Islam. Jika tidak, teknologi informasi akan cenderung menciptakan sistem-sistem yang menjadi otonom dan totaliter. Sistemsistem tersebut tanpa disadari akan menggantikan proses produksi atau bahkan pengetahuan manusia, menciptakan dunia dimana semua prilaku didikte dan disahkan oleh dunia informasi. ${ }^{26}$

Diakui pula bahwa perkembangan teknologi memberikan dampak yang baik bagi masyarakat, seperti pemanfaatan televisi, komputer, dan internet, maka dengan cepat dapat diketahui perkembangan serta kejadian di Indonesia bahkan seluruh dunia. Akan tetapi harus disadari bahwa tidak sedikit pula dampak negatif yang ditimbulkannya. Hal tersebut dapat diamati dari penggunaan berbagai media yang justru merusak citra dan akhlak generasi muda yang bahkan merambah kepada anakanak, yaitu dengan disiarkannya tayangan-tayangan pornografi dan pornoaksi.

Langkah penting bagi umat Islam terkait dengan itu adalah penguasaan ilmu pengetahuan dan teknologi. Adapun teknologi informasi dapat menjadi penunjang pada

\footnotetext{
${ }^{25}$ Ibid., 76-77.

${ }^{26}$ Ibid., 68.
} 
proses penyebaran ilmu pengetahuan ke seluruh umat manusia, termasuk umat Islam. Teknologi informasi patut dimanfaatkan untuk mengurangi jarak antara umat Islam yang berbeda sistem sosial, ekonomi dan politiknya. Teknologi informasi juga diharapkan mampu dipakai untuk mengurangi jarak antara kemajuan yang dicapai oleh negara-negara maju dengan apa yang dicapai oleh negara-negara berkembang. ${ }^{27}$

Menghadapi proses kemajuan dan perubahan zaman sebagai imbas dari kemajuan ilmu pengetahuan dan teknologi, maka kemampuan mengelola informasi menjadi suatu yang tidak dapat diabaikan. Sudah menjadi rahasia umum bahwa arus informasi dunia tak lagi mengenal batas wilayah, kesamaan kepentingan serta sistem sosial dan politik. Bahkan, kendala jarak ruang telah diatasi oleh teknologi transportasi dan telekomunikasi, maka akses informasi telah menyebar dan beragam. Kini produkproduk teknologi dapat dikatakan lebih dominan digunakan untuk mengakses informasi.

Perkembangan teknologi televisi telah dipergunakan semaksimal mungkin untuk memperkecil jarak atau hambatan komunikasi kepada khalayak. Khalayak pada satu sisi menjadi raja dan penentu terhadap lakunya berbagai program yang diproduksi. Khalayak bukan hanya sebagai penonton pasif, tetapi mereka diberi kesempatan untuk merasakan seolah mereka bagian terpenting dari proses transformasi informasi yang berlangsung.

Era globalisasi yang ditandai dengan transformasi ilmu pengetahuan dan teknologi serta komunikasi sudah demikian canggihnya sehingga lebih memudahkan manusia untuk mendapatkan informasi sebagai bahan pengetahuannya. Hasil teknologi modern yang telah memasuki penghidupan manusia merupakan gabungan dari bermacam-macam teknologi.

Bangsa Indonesia pada proses industrialiasi yang mengalir deras dihadapkan pada alternatif-alternatif masa depan seperti:

1. Mengejar keterbelakangan ilmu pengetahuan dan teknologi.

2. Mengembangkan ilmu pengetahuan dan teknologi.

\footnotetext{
${ }^{27}$ Ibrahim, Teknologi Emansipasi dan Transendensi, 191.
} 
3. Memilih proses alih teknologi dan mengadopsinya untuk implementasi praktis. ${ }^{28}$

Terkait dengan orientasi dan usaha-usaha peningkatan pemahaman terhadap Islam, maka teknologi informasi sebagai saluran (channel) dan sekaligus sebagai isi pesan (massage content) memegang peran sangat berarti; ${ }^{29}$ Pertama, teknologi informasi sebagai sarana dakwah dapat diperankan sebagai pembawa informasi tentang ajaran Islam, untuk menyampaikan, mengalihkan atau menjelaskan pikiran, gagasan, pesan kepada umat manusia (kaum muslimin). Di sini, melalui teknologi informasi, seorang mubaligh atau dai melalui pendekatan edukatif persuasif maupun instruktif dapat mengajak atau membangkitkan motivasi umat Islam untuk lebih meningkatkan pemahamannya terhadap ajaran Islam.

Kedua, selain menjadi saluran komunikasi massa sebagai penyebar informasi obyektif, alat pembudayaan serta mobilisator dan dinamisator pengembangan ajaran agama, juga dapat dipergunakan sebagai kontrol sosial yang berupa koreksi dan evaluasi dari masyarakat Islam atas pelaksanaan dakwah yang diselenggarakan, baik oleh pemerintah, tokoh-tokoh agama, maupun lembaga-lembaga dakwah. Dalam memasuki teknologi modern dari teknologi informasi saat ini, maka penguasaan teknologi cetak mutakhir, radio dan televisi yang terbaru serta radio dan video cassette perlu dikuasai dan dimanfaatkan semaksimal mungkin.

Selain media cetak, kini terdapat bermacam-macam media informasi dan komunikasi. Umat Islam juga perlu memiliki media (sarana informasi dan komunikasi elektronik yang efektif seperti televisi, radio, VCD, dan lain-lain untuk dipakai sebagai pusat informasi, guna menyampaikan pesan-pesan Alquran kepada umat manusia seluruh dunia sesuai dengan misi Islam sebagai hudan li al-nās secara cepat dan tepat. Pusat-pusat informasi yang efektif untuk mentransfer situasi sosial ekonomi dan politik kepada umat muslim perlu disiapkan. Umat Islam hendaknya kaya dengan informasi mengenai keberhasilan pembangunan sosial, ekonomi, politik di satu pihak,

\footnotetext{
${ }^{28}$ Jalaluddin Rakhmat, Islam Aktual, Refleksi Sosial Seorang Cendekiawan Muslim (Cet. X; Bandung Mizan, 1998), 210.

${ }^{29}$ Ibid., 211-213.
} 
begitu pula kegagalan pembangunan akhlak di pihak lain, sehingga dapat melakukan evaluasi atau menilai langsung tentang sudah sejauh mana keberhasilan dakwah Islamiyah dalam rangka pembangunan kesejahteraan rakyat.

Hal tersebut tidak hanya didasarkan kepada pemanfaatannya saja, akan tetapi diharapkan dapat memberikan layanan yang bermanfaat bagi seluruh aspek kehidupan manusia. Kemudian hal tersebut memerlukan kemampuan sumberdaya manusia yang handal untuk diaplikasikan secara lebih luas dalam kehidupan bermasyarakat, berbangsa dan bernegara.

\section{Perspektif Hukum Islam terhadap Penggunaan Teknologi Informasi}

Sejarah peradaban manusia mencatat bahwa 50 tahun terakhir peran teknologi informasi dan komunikasi telah menjadi bagian utama penentu gerak peradaban umat manusia. Sebutlah bidang kemanusiaan, apa yang saat ini tidak tersentuh oleh teknologi informasi dan komunikasi ini. Bidang ekonomi, perdagangan, pertahanan keamanan, bidang sosial, pendidikan tidak ada satupun yang tidak tersentuh oleh teknologi informasi dan komunikasi.

Teknologi informasi telah berkembang sangat jauh saat ini dan telah merevolusi cara hidup manusia, baik terhadap cara berkomunikasi, cara belajar, cara bekerja, cara berbisnis, dan lain sebagainya. Era informasi memberikan ruang lingkup yang sangat besar untuk mengorganisasikan segala kegiatan melalui cara baru, inovatif, instan, transparan, akurat, tepat waktu, lebih baik, memberikan kenyamanan yang lebih dalam mengelola dan menikmati kehidupan.

Peningkatan kualitas hidup semakin menuntut manusia untuk melakukan berbagai aktivitas yang dibutuhkan dengan mengoptimalkan sumberdaya yang dimilikinya. Teknologi informasi yang perkembangannya sangat cepat secara tidak langsung mengharuskan manusia untuk menggunakannya dalam segala aktivitasnya.

Sebagai hasil dari kemajuan sains dan ilmu pengetahuan, perspektif Islam melihat teknologi informasi yang bermanfaat adalah apabila: 1) mendekatkan pada kebenaran Allah dan bukan menjauhkannya; 2) dapat membantu umat merealisasikan 
tujuan-tujuannya; 3) dapat memberikan pedoman bagi sesama; dan 4) dapat menyelesaikan persoalan-persoalan umat. ${ }^{30}$

Sejarah telah membuktikan bagaimana kepeloporan teknologi informasi dalam sejarah peradaban masyarakat dunia. Sebelum Eropa menemukan tiga penemuan barunya, yaitu: seni cetak, pemakaian mesin, kompas. Ketiga penemuan ini yang menjadi motor pemercepat tumbuhnya gerakan renaisance, gerakan kelahiran kembali peradaban Eropa yang lahir sejak sekitar abad 14 M. yang kelak menjadi titik awal zaman modern di Eropa, maka jauh sebelumnya di zaman kerajaan Abbasiah (Abad VIII dan X M.) telah banyak tumbuh industri-industri kertas di sekitar negeri Islam. Pada saat itu pembuatan kertas sudah menjadi industri setempat. Kira-kira abad XII M. barulah masuk ke daratan Eropa. ${ }^{31}$

Berbarengan dengan kemajuan industri kertas, penulisan buku-buku baik karya orisinal maupun terjemahan karya Yunani juga ikut berkembang pesat, sehingga tumbuh perpustakaan di mana-mana di wilayah negeri Islam saat itu. Tercatatlah dalam sejarah peradaban bahwa pada abad X M, di Andalusia saja terdapat kurang lebih 20 perpustakaan umum yang mempunyai koleksi 400-600 ribu jilid. $^{32}$

Berdasarkan fakta sejarah, mungkin dapat dilukiskan betapa gemilang dan berperannya teknologi informasi di dunia Islam sebagai sarana meningkatkan pemahaman terhadap Islam dalam kehidupan peradaban manusia, melalui media yang berupa buku-buku, majalah dan bahan lektural lainnya sebagai produk masyarakat muslim. Pada zaman Abbasiah yang mengalami zaman keemasannya saat itu akan menjadi sarana dalam meningkatkan pemahaman terhadap Islam. Bagaimana mungkin gerakan penerus jadi tanpa melalui penerjemahan pengetahuan karya besar cendekiawan Islam seperti al-Kindi, al-Farābi, Ibn Sina, Ibn Rusyd, Ibn Haisam al-Jabir

\footnotetext{
${ }^{30}$ Muhammad Naquib al-Attas, Islam dan Filsafat Sains, terj. Saiful Muzani (Bandung: Mizan, 1995), 44.

${ }^{31}$ Kuntowidjoyo, Dinamika Sejarah Umat Islam Indonesia (Semarang: Sholahuddin Press, $1985), 62$

${ }^{32}$ Ibid., 64 .
} 
dan lainnya. ${ }^{33}$ Itulah fakta sejarah, yang secara historis telah menjadi saksi bagaimana peran teknologi informasi dalam sejarah peradaban umat manusia di dunia serta mengukir andilnya umat Islam dalam sejarah peradaban modern dewasa ini.

Untuk menghadapi berbagai tantangan umat Islam dewasa ini, pers merupakan alat strategis dan sangat relevan untuk dikembangkan di era informasi ini. Pers Islam secara konsepsional tentu memiliki perbedaan normatif dengan jenis-jenis pers lainnya, tetapi secara operasional tentu sama. Jurnalistik Islam sangat tepat jika dikatakan sebagai jurnalistik yang memperjuangkan nilai-nilai tertentu, yakni Islam. Peran strategis pers Islam antara lain, Pertama, pers Islam harus bersikap kritis terhadap lingkungan luar, sanggup menyaring informasi Barat yang relevan dan tidak bias terhadap Islam. Ini sesuai dengan pesan suci Alquran: "Jika orang-orang fasik membawa berita, selidikilah berita itu" (QS al-Hujurāt/49: 6).

Kedua, pers Islam harus mampu menjadi penerjemah dan frontier spirit bagi pembaharuan dan gagasan-gagasan kreatif kontemporer. Di sini, Islam perlu diorientasikan ke depan agar sanggup berbicara dengan berbagai problema sosial dewasa ini dan nanti. Alquran mengatakan: "Hendaknya setiap diri melihat apa yang sudah dipersiapkannya untuk masa depannya, bertakwalah kepada Allah swt." Ketiga, pers Islam hendaknya sanggup melakukan proses sosialisasi sebagai upaya untuk memelihara dan mengembangkan khazanah intelektual Islam. Keempat, pers Islam harus sanggup mempersatukan setiap kelompok umat sambil memberikan kesiapan untuk bersikap terbuka bagi perbedaan paham. Peran pers Islam sebagai dipesankan Alquran: "Dan berpeganglah kamu sekalian dengan tali Allah swt., dan jangan kamu bercerai berai. (QS Ā $\bar{l}$ Imrān/3: 103). ${ }^{34}$

Sehubungan dengan teknologi informasi sebagai sarana dakwah di era informasi di abad modern, diharapkan dapat memberikan manfaat bagi pengembangan dan peningkatan pemahaman terhadap umat Islam atau umat Islam di Indonesia yang

\footnotetext{
${ }^{33}$ Sardar, Information and the Muslim World, 68.

${ }^{34}$ Din Syamsuddin, Etika Agama dalam Membangun Masyarakat Madani (Cet. I; Jakarta: Logos, 2000), 91.
} 
tengah sibuknya bergumul dan berpacu dengan derap pembangunan di segenap sektor kehidupan.

Berikut ini secara operasional peran teknologi informasi dapat dikemukakan beberapa catatan-catatan yang dianggap mampu meningkatkan pemahaman terhadap Islam sebagai berikut:

1. Peran teknologi informasi Islam sebagai sarana dakwah hendaknya mampu memerankan diri sebagai "media dan corong kemajuan bangsa". Artinya mampu berfungsi menjadi sumber informasi objektif, positif, kontrol sosial yang konstruktif, penyalur aspirasi masyarakat Islam atau penyambung kehendak dan minat rakyat, mobilisator dan dinamisator pembangunan serta sebagai mediator antara kepentingan pemerintah dan masyarakat tanpa ada yang terkorbankan kepentingannya. Jikalau teknologi informasi Islam sanggup menjalankan tugasnya dalam pembangunan sebagai media corong kemajuan bangsa seperti itu, maka ia akan mendapat tempat di hati masyarakat Islam khususnya dan masyarakat luas pada umumnya.

2. Teknologi informasi hendaknya sanggup menjadi "media profetik". Artinya ia mesti mampu menjadi pembawa amanat atau risalah agama, yaitu amar makruf dan nahi munkar, menegakkan keadilan dan kebenaran. Di sinilah teknologi informasi yang digunakan sebagai sarana dakwah dengan segenap karakteristik yang islami dan perlu menjalankan fungsi profetik kritisnya dalam rangka partisipasinya dalam pembangunan bangsa Indonesia, dan mampu menjadi suara rakyat dalam menyampaikan dan mengemukakan kritik konstruktifnya kepada golongan sosial yang sedang berkuasa (pemerintah) dengan penuh kebijaksanaan atau "bi al-hikmah wa al-mau'izah al-hasanah"(dengan bijaksana dan nasihat yang baik).

3. Teknologi informasi sebagai sarana dakwah hendaknya mampu menjadi agen pemersatu bangsa Indonesia, terutama dalam rangka mensukseskan pembangunan kerukunan antarumat beragama. Di sini, teknologi informasi sudah saatnya memiliki idealisme yang bersifat nasionalistik-religius, yang orientasinya harus 
diarahkan kepada terciptanya masyarakat yang islami yang sesuai dengan norma kebangsaan dan agama.

4. Teknologi informasi yang merupakan alat komunikasi masyarakat perlu memiliki bahasa yang komunikatif dialogis. Ini dimaksudkan adalah bahasa yang bersifat persuasif-sofistikatif atau bahasa yang mampu menggugah perasaan dan tindakan masyarakat secara halus-lembut, menarik dan indah serta penuh dialog-dialog yang demokratis dan manusiawi. Tanpa bahasa komunikatif dan dialogis ini, teknologi informasi Islam akan tetap sulit meraih hati audiensnya.

5. Teknologi informasi dalam era informasi ini harus dikelola secara lebih profesional. Tanpa "profesionalism oriented", adalah sulit teknologi informasi sebagai sarana dakwah dapat menjadi media yang besar, menarik pembacanya, kompetitif dan dapat merebut pasaran informasi di tengah masyarakat luas dalam era informasi modern yang kian canggih kini dan esok hari. Dengan demikian, penggunaan teknologi informasi sebagai sarana dakwah tidak dapat disangkal bahwa dapat meningkatkan pemahaman masyarakat terhadap Islam. ${ }^{35}$

Sebagai produk ilmu pengetahuan dan sains yang netral, kemajuan dan perkembangan teknologi informasi diharapkan dapat lebih berwajah manusiawi dan lebih memanusiakan manusia, serta lebih bermanfaat sesuai dengan ajaran Islam. Islam tidak mengenal adanya kompartementalisasi bidang-bidang kehidupan manusia, sehingga bidang pengembangan teknologi informasi pun juga merupakan bagian integral kehidupan seorang muslim secara utuh yang harus diorientasikan kepada paradigma kehidupan tauhid. Penguasaan terhadap teknologi informasi dan pemanfaatannya seoptimal mungkin menjadi penting bagi setiap muslim sebagai sarana untuk semakin mendekatkan diri kepada Sang Khalik. Dengan demikian aplikasi teknologi selayaknya sesuai dengan ajaran dan nilai-nilai Islam serta diabadikan kepada nilai-nilai kemanusiaan.

\footnotetext{
${ }^{35}$ Muhammadiyah Amin, "Penerapan Teknologi Informasi dan Komunikasi Guna Menghindari Praktek KKN dalam Rangka Penyelenggaraan Good Governance.” Makalah (Jakarta: Lemhannas RI, 2009), 14.
} 
Penegasan Allah dalam QS al-Hujurāt/49: 12 perlu untuk menjadi renungan untuk membawa perspektif hukum Islam terhadap kemajuan teknologi informasi.

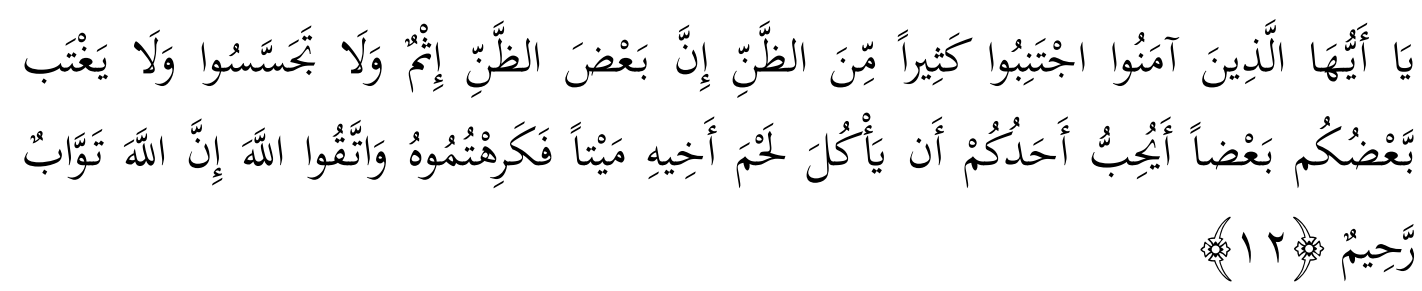

Terjemahnya:

Hai orang-orang yang beriman, jauhilah kebanyakan dari prasangka, sesungguhnya sebagian prasangka itu adalah dosa dan janganlah kamu mencari-cari kesalahan orang lain dan janganlah sebahagian kamu menggunjing sebahagian yang lain. Sukakah salah seorang di antara kamu memakan daging saudaranya yang sudah mati? Maka tentulah kamu merasa jijik kepadanya. Dan bertakwalah kepada Allah. Sesungguhnya Allah Maha Penerima taubat lagi Maha Penyayang. ${ }^{36}$

Ayat tersebut dalam konteks media informasi diemukan ada tiga hal ,yaitu: zann, tajassus, dan ghibah. Zann yang dimaksud pada ayat tersebut adalah prasangka terhadap seseorang yang tanpa disertai indikasi apa pun, semisal menyangka orang baik-baik berbuat mesum atau perbuatan tercela lainnya tanpa bukti. Sehingga dengan demikian, zann (prasangka, asumsi, kecurigaan) yang disertai indikasi indikasi dan bukti yang jelas tent unya tidaklah dilarang. ${ }^{37}$

Sebagai kelanjutannya, pelarangan tajassus tidak berlaku pada usaha membuka aib orang yang berangkat dai żann yang memiliki dalil (indikasi yang jelas). Sehingga investigasi yang dilakukan dengan media massa ataupun teknologi informasi untuk menguak aib seseorang yang disertai indikasi yang kuat akan kebenarannya juga tidak termasuk dalam pelarangan ayat ini. Dalam hal ini 'Abd al-Qāọir Aḥmad 'Aṭa' menulis:

Kita melihat bahwa zann berkembang sedemikian rupa sampai pada taraf tajassus. Zann yang dilarang dalam ayat ini adalah kecurigaan yang tanpa dalil. Ini ditunjukkan bahwa setelah Allah melarang zann, Ia berfirman: walā tajassasü.

\footnotetext{
${ }^{36}$ Kementerian Urusan Agama Islam, Wakaf, dan Irsyad Kerajaan Saudi Arabia, Al-Qur'an dan Terjemahannya (Madinah: Percetakan Al-Qur'an Raja Fadh, 1426 H), 847.

${ }^{37}$ Abū 'Abdullāh Muhammad ibn Ahmad al-Anșāri al-Qurțubī, al-Jamī' al-Aḥām al-Qur'ān, juz XVI (Bairut: Dār al-Kutub al-Ilmìyah, 1993), 331-332; Lihat juga 'Abd al-Qādị Ạmmad 'Aṭa', Hāża Halāl wa Hā̇a Harām (Bairut: Dār al-Kutub al-Alamìah, 1405 H/1985 M), 297.
} 
Andai zann itu didukung oleh bukti yang kuat, niscaya (pelarangan zann) tidak diiringi dengan pelarangan tajassus. Maka dengan demikian, setiap zann yang tidak didukung bukti yang benar, merupakan zann yang haram dan harus dijauhi. ${ }^{38}$

Selanjutnya, yang paling dekat dengan kerja media adalah ghibah. Ghibah artinya menuturkan keadaan seseorang yang jika saja orang itu tahu maka ia akan maran dan tidak senang. Fikih mengancam dengan keras pelaku ghibah. Ungkapan Alquran sangat jelas dalam hal ini. “...Sukakah kamu memakan daging bangkai saudaramu, maka lalu kamu jijik". Besarnya efek yang diakibatkan oleh ghibah menjadi alasan kuat dalam fikih untuk tidak memperkenankannya dalam bentuk apapun, kecuali ada kepentingan lebih besar yang ditujunya (gharadun sahịhụ fỉ alsyar'ī). Tujuan syar'i yang menjadikan ghibah boleh dilakukan, adalah: pertama, altazallum, orang yang menuturkan kebobrokan orang yang menzaliminya untuk menghilangkan kezaliman itu; kedua, al-isti'ānah 'alā taghyïr al-munkar, menuturkan suatu kemungkaran dengan tujuan agar kemungkaran itu ditinggalkan; ketiga, alistifta', menuturkan aib orang kepada ahli hukum (hakim, jaksa, pengacara) untuk mengerti hukumnya; keempat, menuturkan seseorang yang dengan terang-terangan berbuat mungkar (kesaksian di pengadilan); kelima, untuk mewaspadakan umat agar tidak turut melakukan aib yang di-ghibah-i. ${ }^{39}$

Jika alur berpikir ini diteruskan, maka satu-satunya acuan agama yang mesti dipegang oleh pengelola informasi adalah muatan informasi selayaknya mengacu pada tujuan yang benar menurut syarak. Dengan berpegang teguh pada prinsip bahwa segala informasi harus faktual, berimbang, dan bertanggungjawab, maka sejatinya segala bentuk informasi diperbolehkan oleh syarak. Tetapi jika acuannya adalah pertimbangan bisnis dan keinginan pasar, tanpa memperdulikan tanggungjawab moral untuk mendidik masyarakat menjadi semakin baik, maka setiap informasi yang mengarah kepada eksploitasi kekerasan, seksual, dan kriminalitas yang tidak dapat dibenarkan oleh agama dan negara.

\footnotetext{
38، Abd al-Qāḍir Ahmad 'Ața', Hāża Halāl wa Hāża Harām, 298.

${ }^{39}$ Muhammad bin Muhammad al-Ghazāî, Ihyà' Ulūm al-Dìn, juz III (Bairut: Dār al-Fikr, 1989 M/1409 H), 161.
} 
Sebaliknya, dalam konteks informasi yang terkait dengan korupsi, kolusi, manipulasi, perampokan, pencurian, kesewenang-wenangan penguasa, monopoli, dan informasi terkait persoalan rakyat banyak (kepentingan umum), maka semua itu boleh diekspose meskipun menyangkut pelanggaran privasi terhadap oknum-oknum tertentu, karena tujuan yang dimaksud adalah penegakan keadilan dan pemberdayaan masyarakat untuk bersikap tegas terhadap segala bentuk penyelewangan atau penyimpangan. Tetapi, informasi terkait dengan seksualitas, meskipun ada sisi positifnya (agar orang tua lebih ketat mengawasi anak-anaknya), namun imbas negatifnya akan lebih besar. Sebab, di kalangan remaja, informasi seperti itu malah memprovokasi mereka untuk lebih terbuka terhadap seks, dan di kalangan masyarakat luas malah menjadikan mereka bersikap permisif. Informasi tersebut juga melanggar privasi dan aurat pihak yang dijadikan objek ekspose, karena prinsip yang dikedepankan oleh hukum Islam dalam hal-hal yang terkait dengan seksualitas adalah mengupayakan pelaku zina menutup diri dan tidak mengumbar petualangan seksnya. ${ }^{40}$

Dampak negatif dari teknologi informasi tentu tidak sebatas itu saja, sebab globalisasi dan teknologi informasi telah merambah ke seluruh dimensi kehidupan manusia. Untuk itu, diperlukan kembali semangat ijtihad para mujtahid/fukaha dalam menyikapi berbagai problematika yang dimunculkan oleh gelombang globalisasi dan teknologi informasi serta kemampuan melakukan proyeksi masa depan terhadap gejala lainnya yang dapat saja muncul.

Umat Islam diharapkan memiliki landasan, yaitu ajaran Islam itu sendiri. Dalam waktu bersamaan, untuk menghadapi tantangan, maka juga diperlukan landasan, motivasi, inspirasi, dan akidah. Di sini perlu memperkuat dan mempertegas landasan hidup agar mampu menghadapi ancaman dan tehindar dari aspek-aspek mudarat dari pertarungan besar teknologi informasi. Oleh karena itu, perlu diperhatikan dan ditumbuhkan kesadaran kembali tentang tujuan hidup menurut Islam serta bertanggungjawab terhadap perbuatan di dunia dan konsekuensinya di akhirat kelak nanti.

\footnotetext{
${ }^{40}$ Muhammad ibn Ismā'il al-Ṣan’ānī, Subul al-Salām, juz IV (al-Qahirah: Maktabah al-Mujallad al-'Arabi, t.th.), 15.
} 


\section{E. Kesimpulan}

Islam menjunjung tinggi kebebasan pemanfaatan teknologi dan informasi di antara umat manusia. Bahkan Allah memerintahkan manusia selalu berkomunikasi dengan-Nya, memuji kebesaran-Nya, memohon ampunan-Nya, rida-Nya, atau restuNya, perlindungan-Nya dan petunjuk-Nya, adalah sebuah informasi dari manusia kepada Tuhannya. Dari pihak-Nya juga ada penyampaian pesan atau informasi kepada manusia melalui makhluk-makhluk yang dipilih-Nya untuk tugas komunikasi massa di dunia.

Ciri khas teknologi informasi dalam Islam adalah menyebarkan (menyampaikan) informasi kepada pendengar, pemirsa, atau pembaca tentang tentang perintah dan larangan Allah swt, Alquran dan hadis Nabi saw. Pada dasarnya agama sebagai kaidah dan sebagai perilaku adalah pesan (informasi) kepada warga masyarakat agar berperilaku sesuai dengan perintah dan larangan Tuhan.

Sesuai dengan fungsi Islam sebagai rahmat bagi seluruh alam (al-Anbiyā'/21: 107), maka teknologi informasi yang dikembangkan harus membawa rahmat bagi seluruh umat manusia, bukan membawa laknat. Apapun bentuk dan hasilnya, teknologi informasi harus committed pada kebahagiaan umat manusia di dunia dan di akhirat, bukan menciptakan kerusakan di muka bumi (fasād fí al-arḍ). Oleh karenanya, teknologi informasi boleh dikembangkan sejauh mungkin selama berlandaskan etik atau moral yang jelas.

\section{Daftar Pustaka}

'Aṭa', 'Abd al-Qāḍir Aḥmad. Hāża Halāl wa Hāża Harām. Beirut: Dār al-Kutub alAlamiyah, $1405 \mathrm{H} / 1985 \mathrm{M}$.

Amin, Muhammadiyah. "Penerapan Teknologi Informasi dan Komunikasi Guna Menghindari Praktek KKN dalam Rangka Penyelenggaraan Good Governance". Makalah. Jakarta: Lemhannas RI, 2009.

Arsyad, Azhar. Media Pembelajaran. Cet. III; Jakarta: RajaGrafindo Persada, 2002.

Al-Attas, Muhammad Naquib. Islam dan Filsafat Sains, terj. Saiful Muzani. Bandung: Mizan, 1995. 
Azizy, A. Qodri. Membangun Integritas Bangsa. Jakarta: Renaisan, 2004.

Departemen Pendidikan dan Kebudayaan, Kamus Besar Bahasa Indonesia. Cet. IX; Jakarta: Balai Pustaka, 1997.

Echols, Jhon M. and Hassan Shadily, Kamus Inggris Indonesia. Cet. XXI; Jakarta: Gramedia, 1995.

Al-Ghazā̄i, Muhammad bin Muhammad. Ihyā', Ulūm al-Dīn, juz III. Beirut: Dār alFikr, 1989 M/1409 H.

Haedari, HM. Amin, et.al., Masa Depan Pesantren, dalam Tantangan Modernitas dan Tantangan Kompleksitas. Jakarta: IRD Press, 2004.

Hamalik, Oemar. Kurikulum dan Pembelajaran. Cet. III; Jakarta: Bumi Aksara, 2001.

Hawi, Akmal. Kapita Selekta Pendidikan Islam. Palembang: IAIN Raden Fatah, 2005.

Hawkins, Joyce M. Oxford Universal Dictionary. Oxford: Oxford University Press, 1995.

Ibrahim, Marwah Daud. Teknologi Emansipasi dan Transendensi Wacana Peradaban dengan Visi Islami. Cet. II; Jakarta: Mizan, 1995.

Kementerian Urusan Agama Islam, Wakaf, dan Irsyad Kerajaan Saudi Arabia, Al-Qur'an dan Terjemahannya. Madinah: Percetakan Al-Qur'an Raja Fadh, 1426 H.

Kuntowidjoyo. Dinamika Sejarah Umat Islam Indonesia. Semarang: Sholahuddin Press, 1985.

Nata, Abuddin. Paradigma Pendidikan Islam. Jakarta: Rajawali Pers, 2009.

Al-Qurțubī, Abū 'Abdullāh Muhammad ibn Ahmad al-Anșāri. al-Jamī' al-Aḥkām alQur'ān, juz XVI. Beirut: Dār al-Kutub al-Ilmīyah, 1993.

Rakhmat, Jalaluddin. Islam Aktual, Refleksi Sosial Seorang Cendekiawan Muslim. Cet. X; Bandung Mizan, 1998.

Republik Indonesia, Undang-Undang Nomor 11 Tahun 2008 tentang Informasi dan Transaksi Elektronik.

Sa’ud, Udin Saefudin. Inovasi Pendidikan. Cet. I; Bandung: AlfaBeta, 2008.

Al-Ṣan'ānì, Muhammad ibn Ismā'il. Subul al-Salām, juz IV. Kairo: Maktabah alMujallad al-'Arabi, t.th. 
Sardar, Zainuddin. Information and the Muslim World; A Strategy for the Twenty-first Century, terj. Ilyas Hasan, Tantangan Dunia Islam Abad 21; Menjangkau Informasi. Bandung: Mizan, 1988.

Suparni, Niniek. Cyberspace Problematika dan Antisipasi Pengaturannya. Jakarta: Sinar Grafika, 2009.

Syahdeini, Sutan Remy. Kejahatan dan Tindak Pidana Komputer. Jakarta: Pustaka Utama Grafiti, 2009.

Syamsuddin, Din. Etika Agama dalam Membangun Masyarakat Madani. Cet. I; Jakarta: Logos, 2000.

Tim Prima Pena. Kamus Ilmiah Populer: Referensi Ilmiah Ideologi, Politik, Hukum, Ekonomi, Sosial, Budaya dan Sains. Surabaya: Gita Media Press, 2006.

Uno, Hamzah B. dan Nina Lamatenggo, Teknologi Komunikasi dan Informasi Pembelajaran. Cet. II; Jakarta: Bumi Aksara, 2011. 